\title{
Hematological and Blood Biochemical Effects of Fasting and Subsequent Oral Administration of Endotoxin in Prepubertal Gilts
}

\author{
By H. Holst ${ }^{l}$ and H. Kindahl ${ }^{2}$
}

Department of ${ }^{1}$ Clinical Chemistry, and ${ }^{2}$ Obstetrics and Gynaecology, Swedish University of Agricultural Sciences, Uppsala, Sweden.

\begin{abstract}
Holst, H. and H. Kindahl: Hematological and blood biochemical effects of fasting and subsequent oral administration of endotoxin in prepubertal gilts. Acta vet. scand. 1995, 36, 499-508. - The main objective of the present study was to investigate the effects of short-term fasting in gilts on endocrinological and blood biochemical parameters and, further, the effects of subsequent oral endotoxin (ET) administration. Group 1 was fasted for $30 \mathrm{~h}$ and then received feed with ET added. Group 2 was fasted for $30 \mathrm{~h}$ but received standard feed at refeeding. In group 3, gilts were fed every $6 \mathrm{~h}$ for $30 \mathrm{~h}$. The major effects of fasting were: gradually increased concentration of plasma prostaglandin $\mathrm{F}_{2 \alpha}$ metabolite, serum total bilirubin, serum free fatty acids, and decreased serum glucose. The values were normalized within 1-4 h of refeeding. Twelve hours after refeeding, the ET-refed gilts showed higher levels of serum total bile acids and polymorphonuclear leukocytes than those in group 2. It is possible that the observed changes during fasting reflect either an increased intestinal uptake of naturally present endotoxin or a reduced endotoxin detoxifying capacity of the liver. The increased bile acid concentration and polymorphonuclear leukocyte count following refeeding with ET-feed may indicate that orally administered ET is to some extent absorbed from the gut.
\end{abstract}

prostaglandin.

\section{Introduction}

Over the years, considerable efforts have been made to elucidate the role of intestinally derived endotoxin (ET) in the pathogenesis of gastrointestinal and liver-related disorders. The fundamental question, whether ET (or lipopolysaccharide, LPS) can or cannot penetrate the intact gastrointestinal mucosa, has been thoroughly investigated with somewhat contradictory results (Ravin et al. 1960, Truszcynski \& Pilaszek 1969, Wray \& Thomlinson 1972, Gans \& Matsumoto 1974, Cort et al. 1990). The major changes observed in gilts after oral intake of ET-contamined feed are occasional increases in total serum bile acids (S-BA), activity of serum glutamate dehydrogenase (S-GLDH) (Holst et al. 1993a) and a reduced clinical and blood biochemical response to intravenously (i.v.) injected ET following oral intake of ET (Holst et al. 1993b). These findings have been interpreted as the result of an increased uptake of ET from the gut, although not in amounts sufficient to cause systemic endotoxemia.

Probably portal vein endotoxemia (without bacteremia) of intestinal origin must be regarded as a physiological state. The absorbed ET is passed to the liver where it is removed, mainly by the Kupffer cells (Nolan 1988, Fox et al. 1990). The ET load is known to increase in dif- 
ferent gastrointestinal disorders and thereby overload the hepatic detoxifying capacity, as in dogs with hemorrhagic enteritis (Wessels et al. 1987). Malnutrition is another condition that may lead to endotoxemia (Klein et al. 1988). Furthermore it has been shown that protein malnutrition and coexistence of ET can destroy the intestinal mucosal barrier (Deitch et al. 1987). In this context, we found it interesting that high concentrations of 15-ketodihydroprostaglandin $\mathrm{F}_{2 \alpha}$ (P-PG) frequently occur in the first morning blood sample from gilts when $18 \mathrm{~h}$ have passed since the latest feed (Holst et al. 1993a). Due to the luteolytic effect of primary PGF $_{2 \alpha}$, periods of feed deprivation could thus be deleterious to pregnant animals. As P-PG is a well known marker for ET influence (Fredriksson et al. 1985), one might further speculate that the elevated P-PG concentrations observed during fasting reflect intestinal permeability changes and an increased ET uptake from the intestine. The main objective of the present study was to investigate the endocrinological and blood biochemical effects of shortterm fasting in gilts and, further, the effects of subsequent oral ET administration.

\section{Materials and methods}

\section{Experimental animals and design}

Twelve prepubertal Yorkshire $\times$ Landrace $\times$ Hampshire crossbred gilts from 4 different litters from a commercial farm were used. Body weights (b.w.) ranged between 28 and $38 \mathrm{~kg}$ on arrival ( 2 weeks before the experiment), and the gilts were kept in individual pens on wood shavings throughout the study. The animals were fed twice daily ( 9 a.m., 3 p.m.) with $0.7 \mathrm{~kg}$ of commercially prepared pelleted feed (energy content $12 \mathrm{MJ} / \mathrm{kg}$ ). Two days prior to commencement of the experiment, feed was given 4 times daily ( 9 a.m., 3 p.m., 9 p.m. and 3 a.m.; $0.35 \mathrm{~kg}$ each). The feed was mixed with water $(400$ $\mathrm{ml} / \mathrm{kg}$ ) to a consistency of stodgy porridge. Wa- ter was provided ad libitum. Six days before the experiment, a jugular venous catheter was surgically inserted (Rodriguez \& Kunavongkrit 1983) under general anesthesia. Trimethoprimsulfadoxin, $15 \mathrm{mg} / \mathrm{kg}$ b.w. i.v., was given for 3 days after surgery. The catheters were flushed daily with heparinized physiological saline (25 $\mathrm{IE} / \mathrm{ml} \mathrm{NaCl}$ ) with an additive of benzyl-penicillin-potassium $(1 \mathrm{mg} / \mathrm{ml} \mathrm{NaCl}$; omitted $24 \mathrm{~h}$ before the experiment).

Three experimental groups were used consisting of 1 gilt from each of the 4 litters. Group 1 was fasted for $30 \mathrm{~h}$ (last feeding at 3 a.m.). At 9 a.m. the following day, they were fed with 0.35 $\mathrm{kg}$ each of standard feed containing $100 \mathrm{mg}$ LPS from Escherichia coli (O55:B5, phenolextracted, batch 17F-40191, Sigma, St. Louis, USA). Group 2 was also fasted for $30 \mathrm{~h}$ but received standard feed at refeeding. In group 3, which was housed in a separate part of the building, the gilts were fed every $6 \mathrm{~h}$ for $30 \mathrm{~h}$ and thereby served as a control group during the fast. After the fasting interval, groups 1 and 2 were fed as before with standard feed at $6 \mathrm{~h}$ intervals for $24 \mathrm{~h}$. The standard feed was checked for background content of unspecified ET with the Limulus amoebocyte lysate test (LAL) originally developed for plasma measurement (Goto \& Rylander 1987, Holst et al. 1994) and was found to contain about $16 \mathrm{mg} / \mathrm{kg}$ of feed. The ET feed was prepared $6 \mathrm{~h}$ before feeding by dissolving $400 \mathrm{mg}$ of ET in $560 \mathrm{ml}$ water which was mixed with $1.4 \mathrm{~kg}$ feed. As determined with the LAL test, the ET feed contained $110 \mathrm{mg} / \mathrm{kg}$ of feed, which is comparable to what has been detected in naturally ET-contaminated feed (R. Rylander, personal communication). Except for the addition of ET, the standard feed was pretreated in the same way as the ET feed. In all cases, the feed was completely consumed. Some $27-30 \mathrm{~h}$ after refeeding, the animals were euthanized and autopsy and fecal parasitological examinations were 
performed. Tissue samples from the liver were taken and fixed in $4 \%$ formaldehyde for histopathological examination.

\section{Blood sampling and analytical methods}

At each blood sampling, jugular vein blood was aspirated through the venous catheter into a plastic syringe (Becton \& Dickinson, Rutherford, New Jersey, USA) and transferred to plain, heparinized and EDTA vacutainer tubes (Becton \& Dickinson) for serum, plasma, and hematological analyses, respectively. The first blood sample was taken in connection with the last feeding at 3 a.m., the 2nd after $6 \mathrm{~h}$, then samples were taken every 3 h to 9 a.m. From 9 p.m. to 9 a.m., additional blood samples, heparinized tubes only, were collected every hour. After refeeding at 9 a.m., samples were taken every $2 \mathrm{~h}$ for $12 \mathrm{~h}$ and every $3 \mathrm{~h}$ for the last 12 $\mathrm{h}$ of the study. In half of the gilts of groups 1 and 2 , an additional blood sample was taken $1 \mathrm{~h}$ after refeeding. In connection with refeeding and 2, 4, and $6 \mathrm{~h}$ later, samples were taken for endotoxin determination. Rectal temperature was measured and clinical status recorded in connection with the blood samplings.

With some exceptions, all procedures concerning the storage of the blood samples and the methods for the blood biochemical and the hematological analyses were as described earlier (Holst et al. 1993a): serum total bile acids (S-BA), serum total bilirubin (S-TB), serum conjugated bilirubin, serum glutamate dehydrogenase (S-GLDH), serum glucose (S-GLUC), serum free-fatty acids (S-FFA), serum triglycerides (S-TRIG), plasma cortisol (P-CORT), plasma prostaglandin $\mathrm{F}_{2 \alpha}$ metabolite (15-ketodihydro- $\mathrm{PGF}_{2 \alpha}$ ) (P-PG), red blood cells (B-RBC), total white blood cells (B-WBC), and differential white blood cell count. Serum concentrations of conjugated bilirubin and B-RBC were analysed at 9 a.m. on the first 2 experimental days.
Analyses of S-BA, S-TB and conjugated bilirubin (Bilirubin Test, no. 071003, Roche, Basle, Switzerland) were made on serum stored at $-20^{\circ} \mathrm{C}$ for 7 days, and on fresh serum for S-GLDH (Test-Combination GLDH activated, no. 124320, Boehringer Mannheim Diagnostica, Mannheim, Germany), using spectrophotometric methods. Determinations of S-GLUC (Gluc HK, no. 0736724, Roche), S-FFA (NEFAC, no. 994-75409, Wako Chemicals, Neuss, Germany) and S-TRIG (Triglycerides PAP, nos. 0722154, 0722162, Roche) were made on serum stored at $-20^{\circ} \mathrm{C}$, using a spectrophotometric multichannel analyser (Cobas Fara, Roche). Analysis of P-CORT was performed on plasma stored at $-20^{\circ} \mathrm{C}$ with an enhanced chemiluminescence immunoassay (Amerlite cortisol assay, no. LAN. 0801, Kodak Clinical Diagnostics Ltd, Amersham, Bucks, England) evaluated for porcine plasma (Magnusson et al. 1994). The interassay coefficients of variation for S-TB and S-GLUC were $1.9 \%$ (mean value $36.2 \mu \mathrm{mol} / \mathrm{l}$ ) and $2.7 \%$ (mean value $7.5 \mathrm{mmol} / \mathrm{l})$, respectively. Differentiation of white blood cells into polymorphonuclear (neutrophils, basophils and eosinophils) (PMN) and mononuclear (monocytes, macrophages and lymphocytes) (MN) were made by light microscope counting of 200 cells on MayGrünwald/Giemsa stained blood smears that were prepared at the latest $6 \mathrm{~h}$ after the sample was taken. Determination of endotoxin in serum samples (half of the animals in each group) collected at refeeding and 2, 4 and $6 \mathrm{~h}$ thereafter was done with the LAL-test (chromogenic substrate, performed by Dept. Clin. Chem., University Hospital, Uppsala, Sweden). The effect of 7 days of storage at $-20^{\circ} \mathrm{C}$ had earlier been checked for S-BA, S-TB and conjugated bilirubin, and the values were found not to differ appreciably from analysis data on fresh serum. 

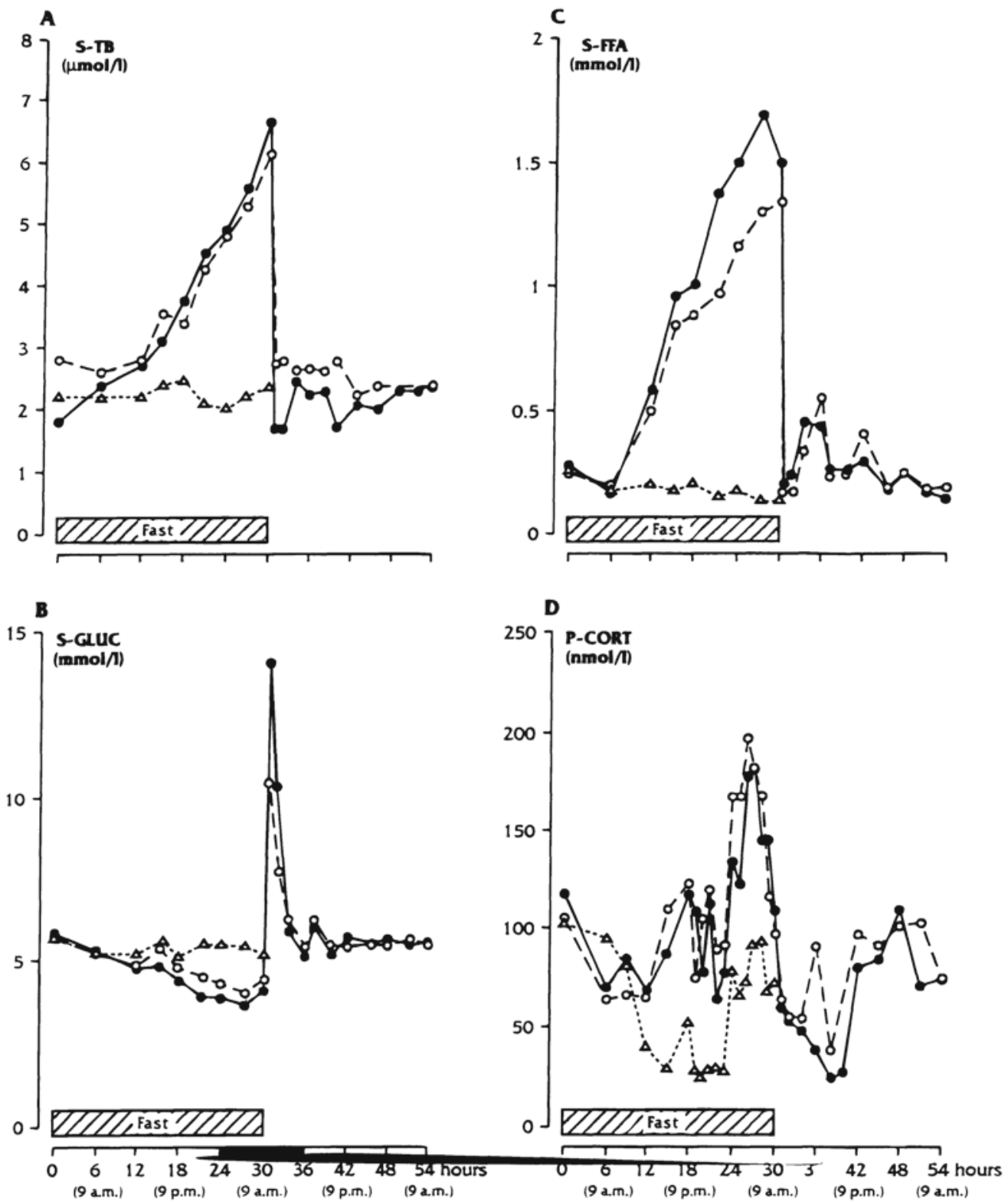

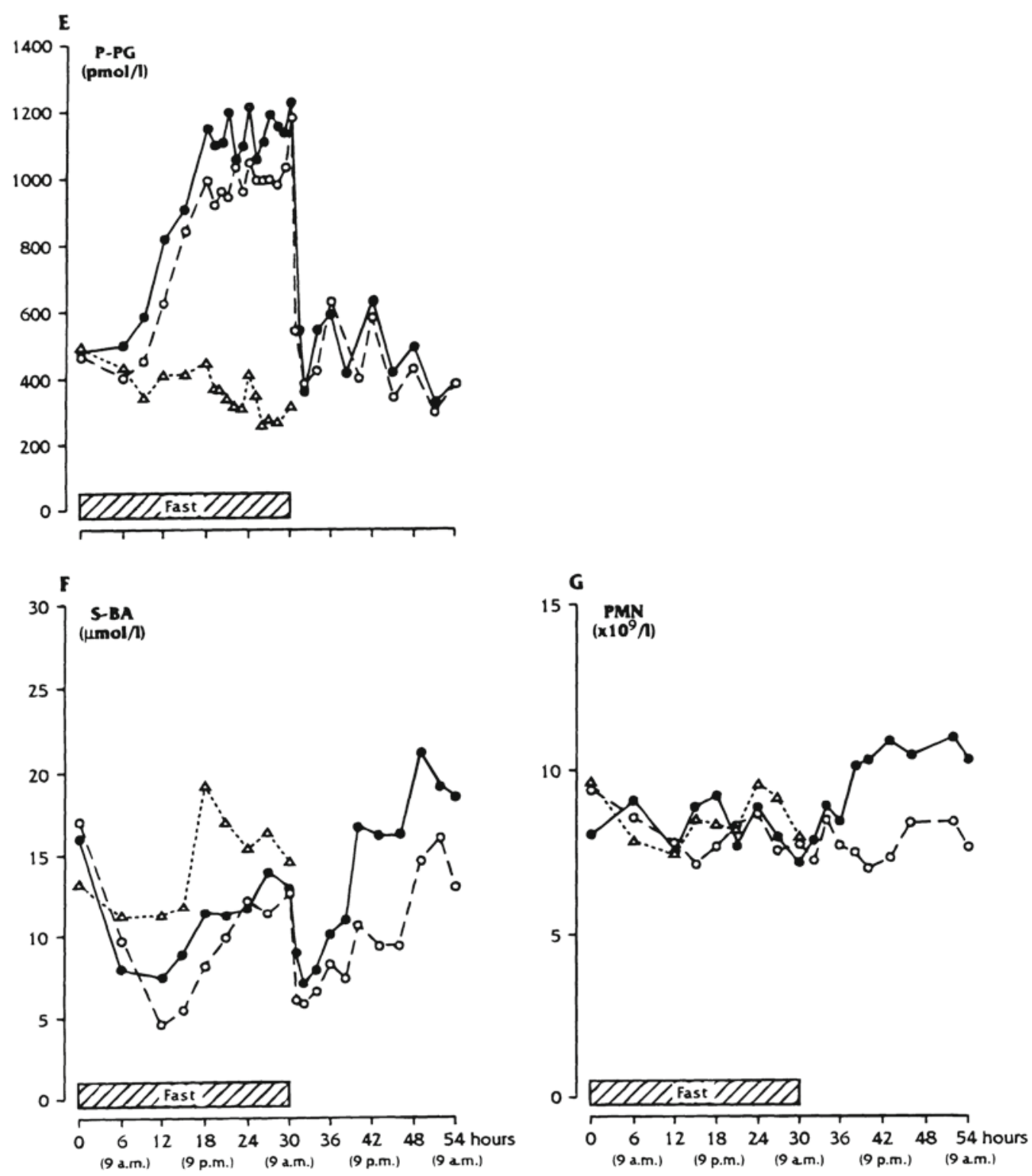

Figure 1A-G. Mean concentrations of various blood parameters over time in gilts that were fasted for $30 \mathrm{~h}$ and refed with endotoxin feed (group $1 ; n=4 ;-\bullet$ ), gilts fasted for $30 \mathrm{~h}$ and refed with ordinary feed (group 2; $n=4 ; \bigcirc---\bigcirc$ ), and gilts fed with ordinary feed every $6 \mathrm{~h}$ for $30 \mathrm{~h}$ (group $3 ; n=4 ; \Delta--\Delta$ ). A: serum total bilirubin (S-TB); B: serum glucose (S-GLUC); C: serum free-fatty acids (S-FFA); D: plasma cortisol (P-CORT); E: plasma 15-ketodihydro-PGF ${ }_{2 \alpha}$ (P-PG); F: serum total bile acids (S-BA); and G: blood polymorphonuclear leukocytes (PMN). 


\section{Statistical analyses}

The data derived from the determinations of S-BA, S-TB, S-GLDH, S-GLUC, S-FFA, S-TRIG, P-CORT, P-PG, B-WBC, PMN, MN, and rectal temperature were analysed in terms of mean value for the whole $30 \mathrm{~h}$ fasting interval, and $\mathrm{B}-\mathrm{RBC}$ and conjugated bilirubin, in terms of change within animal during the last $24 \mathrm{~h}$ of the fasting interval, respectively. Differences between fasted (groups 1 and $2 ; n=8$ ) and non-fasted (group $3 ; n=4$ ) gilts were evaluated statistically using the Mann-Whitney $\mathrm{T}$ statistic (Altman 1991).

In the second part of the study, the data concerning each gilt were first transformed by subtracting the mean value of all time points in the fasting interval (before ET exposure), from the subsequent time points. The differences within pairs $(n=4)$ (experimental gilt minus littermate control) were calculated for all time points in all parameters. The S-BA, S-TB, S-TRIG, $\mathrm{B}-\mathrm{WBC}, \mathrm{PMN}$, and $\mathrm{MN}$ data were then evaluated in terms of mean value of the differences within matched pairs. Concerning the S-GLUC, S-FFA, P-PG, P-CORT and temperature data the evaluation was made in terms of mean value of the data from the time point where the maximum difference (regardless of sign) occurred plus the data from the 2 closest time points. In parameters where the respective summary measure for all 4 matched pairs had the same sign $(p<0.2$ due to Wilcoxon matched pair sign test), the outcome is denoted in the text as a difference as compared to the control group. Concerning both parts of the study, the data are also described in the text and shown in the figures as mean values within group for different time points.

\section{Results}

\section{Effects of fasting}

In the fasted animals (groups 1 and 2), S-TB increased gradually from about 2 to $6 \mu \mathrm{mol} / 1$ dur- ing the $30 \mathrm{~h}$ of fasting (Fig. 1A) and the mean concentration was higher than in the control group $(p<0.01)$ (group 3). This increase was mainly due to an increase in the free bilirubin fraction, as the increase in the conjugated bilirubin concentration was small; from a mean value of 0.5 to $0.8 \mu \mathrm{mol} / 1$ ( $p<0.05$; data not shown). The serum glucose concentration decreased from approximately 6 to $4 \mathrm{mmol} / \mathrm{l}$ (Fig. 1B) and when compared with the control group, the mean concentration was lower $(p<0.05)$ during the $30 \mathrm{~h}$ of fasting. After $12 \mathrm{~h}$ of fasting, the S-FFA started to rise and showed a more than fourfold increase toward the end of the fast (Fig. 1C). The mean concentration was higher than in the control group $(p<0.01)$. In both the fasted and the non-fasted gilts, the P-CORT reached its highest levels between 3 to 7 a.m. (90-200 nmol/1). As of $12 \mathrm{~h}$ of fasting, the concentration was about twice as high in the fasted animals (Fig. 1D) and in terms of mean concentration, they showed higher values compared with the controls $(p<0.01)$. After $9 \mathrm{~h}$ of fasting, the P-PG started to increase from about 500 and reached $1000 \mathrm{pmol} / \mathrm{l} 9 \mathrm{~h}$ later. The concentrations then remained at that level for the rest of the period (Fig. 1E) and with a higher mean value than in the control animals $(p<0.01)$. The red blood cell concentration decreased during the last $24 \mathrm{~h}$ of fasting by about $3 \%$ and $11 \%$ in the fasted and non-fasted gilts, respectively (data not shown). However, the difference between the groups was not statistically significant. The determinations of S-BA, S-GLDH, S-TRIG, B-WBC, differential white blood cell count, and rectal temperature did not reveal any statistically significant differences between the fasted and non-fasted animals.

\section{Effects of refeeding and endotoxin}

Following refeeding, the ET-fed gilts (group 1) showed no obvious clinical signs of illness, but had higher mean S-BA than the standard-fed 
gilts (group 2) for $24 \mathrm{~h}$ (Fig. 1F). Within $1 \mathrm{~h}$ of refeeding, both the ET- and standard-fed gilts had markedly increased S-GLUC, and the concentrations had returned to the pre-fasting level $3 \mathrm{~h}$ later. Furthermore, during this initial peak, the ET-fed animals had higher concentrations than the standard-fed group (Fig. 1B). The PMN counts in the two groups differed following refeeding in terms of a gradual increase in the ET-fed group, that lasted to the end of the observation period (Fig. 1G). Concerning S-TB, S-FFA and P-PG, the concentrations had returned to the respective pre-fasting levels within one hour of refeeding (Figs. 1A; C and E), but as with the S-GLDH, S-TRIG, P-CORT, $\mathrm{B}-\mathrm{WBC}, \mathrm{MN}$ and temperature data, there were no differences between the groups. The serum concentrations of endotoxin were low (around $10-15 \mathrm{ng} / \mathrm{l}$ ) in practically all the analysed samples. The postmortem macroscopical and histopathological examination produced no pathological findings. The faecal parasitological examination did not reveal any presence of intestinal parasites.

\section{Discussion}

Prostaglandins of the $\mathrm{F}$ series are regarded as sensitive markers for ET influence. Several possible mechanisms have to be considered when interpreting the pattern of changes in P-PG during fasting and in connection with refeeding. In total parenteral nutrition in the rat, it has been shown that gut structure changes occur (Meurling \& Roos 1981), and further, an increased delivery of ET to the portal circulation takes place (Gonella et al. 1992). Malnutrition is associated with systemic endotoxemia in man (Klein et al. 1988) as well as portal endotoxemia in experimental animal models (Miyagawa et al. 1992). It is therefore intriguing to speculate that a fasting-induced increase in intestinal permeability and subsequently increased absorption of naturally present ET from the gut, may be the cause of the increased P-PG values. However, following refeeding, the ET-fed gilts did not show higher P-PG values than the controls, as would have been expected if the permeability had increased, provided the refeeding per se did not rapidly normalize the intestinal permeability. Both the increase in P-PG concentrations during fasting and the immediate return to pre-fasting levels after refeeding find support in fasting experiments in pregnant mares (Silver \& Fowden 1982). As an explanation, these authors suggested that the simultaneous increase in S-FFA and S-TRIG might increase the concentration of arachidonic acid, the precursor of prostaglandin synthesis. However, we could not detect any change in S-TRIG in the present study. Additionally, it has been shown in the pig that the hepatic clearance of indocyanine green is depressed in the fasting state, possibly due to a mechanism similar to that of a reduced bilirubin clearance (Kudsk et al. 1992). As ET in portal blood is detoxified in the liver, the possible event of a reduced hepatic clearance of naturally present ET in portal blood during fasting, could constitute an alternative hypothesis to explain the increased P-PG during fasting.

In both groups of animals, S-BA levels increased after refeeding. The higher concentrations detected in the ET-fed gilts are consistent with our earlier investigations (Holst et al. 1993a) and probably indicate a certain uptake of orally administered ET. Also the higher PMN counts in the ET-refed gilts can most likely be explained by ET absorption and are consistent with earlier described effects of ET on the white blood cell picture in the pig (Holst et al. 1993b). In these 2 studies, neither the S-BA nor the PMN increase has been accompanied by an increase in P-PG. Perhaps a fastinginduced increase in intestinal permeability causes a quantitatively larger uptake of naturally present ET than the uptake of feed-derived 
ET in the non-fasted state. At least the lack of increase in S-BA during fasting could be reasonably explained by a lowered hepatic secretion and enterohepatic recirculation of bile acids.

The change in S-FFA during fasting in the present study agrees remarkably well with data published by others (Warris \& Brown 1983), where a fourfold increase was detected. The simultaneously occurring increases in S-FFA and P-PG are interesting, since not only prostaglandin $\mathrm{E}$ but also prostaglandin $\mathrm{F}$ is known to have antilipolytic properties (Crandall et al. 1987). In our study, S-GLUC decreased two to three times more during fasting than has earlier been reported in the pig (Warris \& Brown 1983). These authors also showed that over $50 \%$ of the liver glycogen had been lost by $9 \mathrm{~h}$, and practically all of it, at $18 \mathrm{~h}$ after feed withdrawal. This is worth mentioning, as liver glycogen is considered to be a protective substrate resource in endotoxin shock (Esahili et al. 1991). To speculate, the glycogen depletetion of the liver in the fasting state might be connected with the P-PG increase in terms of a reduced ET detoxifying capacity. The higher S-GLUC immediately after refeeding with ET-feed in the present study can hardly be interpreted as other than having been caused by the orally administered ET. Initial transient hyperglycemia have been described in ET shock (Hinshaw 1976).

The highest P-CORT found in our study was detected between 3 and 7 a.m., i.e. differing somewhat from an earlier investigation (Barnett et al. 1981) where peak concentrations in general occurred around 9 a.m. In contrast to the results of Warris \& Brown (1983), we could show increased P-CORT as an effect of fasting, which is certainly an expected finding in a stressful situation, and confirmed also by others (Andersson 1988). Since it has been shown that both endogenous and exogenous glucocorticoids reduce the ET-induced cytokine release
(Parant et al. 1991, Barber et al. 1993), one might hypothesize that the increased concentrations of endogenous glucocorticoids here could have a beneficial effect in protecting the animals from intestinally derived ET and its mediators. The pattern of the change in the S-TB values corresponds closely to earlier investigations, especially when considering the positive correlation between S-TB and S-FFA, which has also been demonstrated in man (Cowan et al. 1977) and horse (Naylor et al. 1980). The reason why fasting hyperbilirubinemia occurs is probably that the mobilized free fatty acids interfere with the hepatic clearance of unconjugated bilirubin, which would be a mechanism quite consistent with the rapid normalization of both the S-TB and S-FFA values that occurred within one hour of refeeding.

In the present study, we were able to detect changes, induced by fasting per se as well as the subsequent oral ET administration, that might indicate increased uptakes of naturally gutderived and feed-derived ET, respectively. Furthermore, for the first time data are presented on fasting-induced increases in P-PG and S-TB in the pig. The mechanism underlying the changes in the prostaglandin profile await clarification, but our results show the extreme importance of taking into consideration the feeding regime when designing experimental models in the pig where prostaglandins of the $\mathrm{F}$ series are to be studied. Since feed deprivation is a relatively common phenomenon in the pig, the fasting-induced increase in P-PG might have a practical importance to pregnant animals, causing reduced embryo survival or abortion.

\section{Acknowledgement}

The present study was supported by the Swedish Council for Forestry and Agricultural Research, the Farmers' Research Council for Information and Development, and the Michael Forsgren Foundation. 


\section{References}

Altman DG: Practical statistics for medical research. 1991. Chapman and Hall, London.

Andersson I: Fasting and withdrawal of management of growing pigs in a simulated emergency situation. Observations on health, behaviour, performance and some blood serum constituents. Swedish J. agric. Res. 1988, 18, 119-128.

Barber AE, Coyle SM, Marano MA, Fischer E, Calvano SE, Fong Y, Moldawer LL, Lowry SF: Glucocorticoid therapy alters hormonal and cytokine responses to endotoxin in man. J. Immunol. 1993, 150, 1999-2006.

Barnett JL, Winfield CG, Cronin GM, Makin AW: Effects of photoperiod and feeding on plasma corticosteroid concentrations and maximum corticosteroid-binding capacity in pigs. Aust. J. Biol. Sci. 1981, 34, 577-585.

Cort $N$, Fredriksson $G$, Kindahl H, Edqvist LE, Rylander $R$ : A clinical and endocrine study on the effect of orally administered bacterial endotoxin in adult pigs and goats. J. Vet. Med. 1990, A 37, 130-137.

Cowan RE, Thompson RPH, Kaye JP, Clark GM: The association between fasting hyperbilirubinemia and serum non-esterified fatty acids in man. Clin. Sci. Mol. Med. 1977, 53, 155-163.

Crandall DL, Vu V, Lizzo FH, Davis BA, Cervoni P: Antilipolytic activity of Viprostol, a transdermally active antihypertensive $\mathrm{PGE}_{2}$, analog. Prostaglandins 1987, 33, 767-773.

Deitch EA, Winterton J, Li M, Berg R: The gut as a portal entry for bacteremia. Ann. Surg. 1987, 205, 681-692.

Esahili AH, Boija PO, Ljungqvist $O$, Rubio $C$, Ware $J$ : Twenty-four hour fasting increases endotoxin lethality in the rat. Eur. J. Surg. 1991, 157, 89-95.

Fox ES, Thomas P, Broitman SA: Hepatic mechanisms for clearance and detoxification of bacterial endotoxins. J. Nutr. Biochem. 1990, 1, 620628.

Fredriksson $G$, Kindahl H, Edqvist LE: Endotoxin induced prostaglandin release and corpus luteum function in goats. Anim. Reprod. Sci. 1985, 8, 109-121.

Gans H, Matsumoto $K$ : Are enteric endotoxins able to escape from the intestine? Proc. Soc. Exp. Biol. Med. 1974, 147, 736-739.

Gonella PA, Helton WS, Robinson M, Wilmore DW: O-Side chain of Escherichia coli endotoxin O111:B4 is transported across the intestinal epithelium in the rat: evidence for increased trans- port during total parenteral nutrition. Eur. J. Cell Biol. 1992, 59, 224-227.

Goto H, Rylander R: Kinetics of inhaled lipopolysaccharide in the guinea pig. J. Lab. Clin. Med. 1987, 110, 287-291.

Hinshaw LB: The role of glucose in endotoxin shock. Circ. Shock 1976, 3, 1-10.

Holst H, Edqvist LE, Kindahl H: Reduced response to intravenous endotoxin injections following repeated oral administration of endotoxin in the pig. Acta vet. scand. 1993b, 34, 405-419.

Holst H, Edqvist LE, Kindahl H, Rylander R: Effects of oral and intravenous administration of endotoxin in prepubertal gilts. J. Vet. Med. 1993a, $A$ 40, 33-44.

Holst H, Edqvist LE, Kindahl H, Rylander R: Hematological, blood biochemical, and cytological bronchoalveolar lavage studies in prepubertal gilts after endotoxin inhalation and ingestion. $\mathrm{J}$. Vet. Med. 1994, A 41, 159-166.

Klein K, Fuchs J, Kulapongs P, Mertz G, Suskind RM, Olson RE: Endotoxemia in protein energy malnutrition. J. Pediatr. Gastroenterol. Nutr. 1988, 7 , 225-228.

Kudsk KA, Kisor DF, Waters B, Mirtallo JM, Campbell $A J$, Wooding-Scott RA: Effect of nutritional status on organic anion clearance by the swine liver. Surgery 1992, 111, 188-194.

Magnusson U, Holst H, Kindahl H, Karlsson A: Effect of mimicking prepartum concentration of estradiol- $17 \beta$ on the inflammatory response to endotoxin in gilts. Am. J. Vet. Res. 1994, 55, 785-789.

Meurling $S$, Roos $K A$ : Gut structure changes in rats on continuous and intermittent complete parenteral nutrition. Acta Chir. Scand. 1981, 147, 451457.

Miyagawa S, Numata M, Ichikawa H, Makuuchi M: Portal endotoxemia during obstructive jaundice. Med. Sci. Res. 1992, 20, 99-100.

Naylor JM, Kronfeld DS, Johnson K: Fasting hyperbilirubinemia and its relationship to free fatty acids and triglycerides in the horse. Proc. Soc. Exp. Biol. Med. 1980, 165, 86-90.

Nolan JP: The role of intestinal endotoxins in gastrointestinal and liver diseases. In: Progress in Clinical and Biological Research, vol. 272: Bacterial Endotoxins; Pathophysiological Effects, Clinical Significance and Pharmacological Control, eds. Levin J, Büller HR, Ten Cate JW, van Deventer SJH, Sturk A. 1988, New York; Alan R Liss inc., 147-159. 
Parant M, Le Contel C, Parant F, Chedid L: Influence of endogenous glucocorticoid on endotoxininduced production of circulating TNF- $\alpha$. Lymph. Cyt. Res. 1991, 10, 265-271.

Ravin HA, Rowley D, Jenkins C, Fine J: On the absorption of bacterial endotoxin from the gastrointestinal tract of the normal and shocked animal. J. Exp. Med. 1960, 112, 783-792.

Rodriguez H, Kunavongkrit A: Chronical venous catheterization for frequent blood sampling in unrestrained pigs. Acta vet. scand. 1983, 24, 318320.

Silver M, Fowden AL: Uterine prostaglandin $\mathrm{F}$ metabolite production in relation to glucose availability in late pregnancy and a possible influence of diet on time of delivery in the mare. J. Reprod. Fert. 1982, 32, 511-519.

Truszczynski M, Pilaszek $J$ : Effects of injection of enterotoxin, endotoxin or live culture of Escherichia coli into the small intestine of pigs. Res. Vet. Sci. 1969, 10, 469-476.

Warris $P D$, Brown $S$ : The influence of preslaughter fasting on carcass and liver yield in pigs. Livest. Prod. Sci. 1983, 10, 273-282.

Wessels BC, Gaffin SL, Wells MT: Circulating plasma endotoxin (lipopolysaccharide) concentrations in healthy and hemorrhagic enteric dogs: antiendotoxin immunotherapy in hemorrhagic enteric endotoxemia. J. Am. Anim. Hosp. Assoc. 1987, 23, 291-295.

Wray C, Thomlinson JR: The effects of Escherichia coli endotoxin in calves. Res. Vet. Sci. 1972, 13, 546-553.

\section{Sammanfattning \\ Hematologiska och blodkemiska effekter av fasta och därpå följande oral administrering av endotoxin hos svin}

Permanenta venkatetrar inopererades på tolv icke könsmogna gyltor av treraskorsning (28-38 kg kroppsvikt) en vecka före försökets början. Djuren delades in i 3 grupper $(n=4)$. Gyltorna i grupp 1 fastades i 30 timmar varefter de utfodrades med foder med tillsats av endotoxin (Escherichia coli; $100 \mathrm{mg}$ per djur). Grupp 2 fastades också i 30 timmar men erhöll vanligt foder vid återutfodring. Djuren $\mathrm{i}$ den tredje gruppen utfodrades, under motsvarande 30 timmar, var sjätte timme och tjänade därigenom som kontroller till de andra djuren under fasteintervallet. Blodprover togs regelbundet under fasteperioden, samt i 24 timmar efter återutfodring (ej grupp 3).

På de fastade djuren uppmättes bl.a. gradvis stigande blodkoncentrationer av prostaglandin $\mathrm{F}_{2 \alpha}$-metabolit, fria fettsyror och totalbilirubin. Värdena normaliserades inom några timmar efter återutfodring. Efter utfodring uppvisade de gyltor som endotoxinutfodrats högre blodkoncentrationer av gallsyror och polymorfkärniga leukocyter än de normalutfodrade djuren. Det är möjligt att de förhöjda koncentrationerna av prostaglandin $\mathrm{F}_{2 \alpha}$-metabolit under fasta orsakas av antingen en förändrad tunntarmspermeabilitet och därigenom ett ökat upptag av i tarmen naturligt förekommande endotoxin, eller en försämrad endotoxindetoxifierande kapacitet i levern. De uppmätta förändringarna efter endotoxinutfodring talar för att oralt administrerat endotoxin, efter fasta, i viss utsträckning tas upp från magtarmkanalen till portablodet.

(Received January 10, 1995; accepted June 22, 1995).

Reprints may be obtained from: H. Hohlst, Department of Clinical Chemistry, Swedish University of Agricultural Aciences, P.O. Box 7038, S-75007, Uppsala, Sweden. 